\title{
The non-technical skills needed by graduates of technical colleges in metalwork technology
}

\author{
Bakare Shola F ${ }^{1}$, Azlan Abdul Latib ${ }^{2}$, Rosmah Samari ${ }^{3}$, Yusri Kamin ${ }^{4}$, Muhammad Sukri Saud ${ }^{5}$, \\ Nor Fadila Amin 6 \\ ${ }^{1}$ Department of Vocational and Technical Education, Adekunle Ajasin University, Nigeria \\ 2,3,4,5,6 Department of Technical and Engineering Education, School of Education, \\ Universiti Teknologi Malaysia, Malaysia
}

\section{Article Info \\ Article history: \\ Received Aug 27, 2019 \\ Revised Oct 27, 2019 \\ Accepted Nov 29, 2019}

\section{Keywords:}

Future employment

Graduates

Metalwork technology

Non-technical skills

Technical colleges

\begin{abstract}
This study centered on the views of the professionals about the non-technical skills considered crucial as recruitment prerequisite among graduates of metalwork technology from technical and vocational institutions in Nigeria. It will also examine the possibility of integrating these skills into the curriculum. The study made use of the survey research design. One research question guided the study. The population for the study comprised metalwork technology professionals in Ogun State, Southwestern Nigeria. A 36-item questionnaire was the instrument used for data collection. The instrument was validated by experts from the University of Lagos (UNILAG). The reliability of the instrument was determined using Cronbach Alpha and the reliability index which stood at 0.79 . The data collected were analysed using mean statistic and standard deviation. The study revealed that professionals placed great importance on communication skills, problem-solving skills, teamwork skills and self-management qualities among others, as important recruitment prerequisite among graduates of metalwork technology from technical and vocational institutions in Nigeria. The study concludes with the suggestions that non-technical skills should be integrated into the curriculum particularly in the field of metalwork technology in technical colleges. Students should be familiar with the employers' recruitment criteria while they are still in schools in order to equip them with the necessary skills needed for employment.
\end{abstract}

Copyright $@ 2019$ Institute of Advanced Engineering and Science. All rights reserved.

\section{Corresponding Author:}

Bakare Shola F.,

Department of Vocational and Technical Education,

Adekunle Ajasin University,

Akungba-Akoko, 340001 Nigeria.

Email: shola.bakare@aaua.edu.ng

\section{INTRODUCTION}

The existing gap between the skills acquired by graduates and those required by employers is so wide that most of the graduates are finding it difficult to get employed [1,2]. It has been reported by many scholars that fresh graduates face problems to secure suitable employment. There is also no doubt that the issue of displeasure over the performance of graduates has been underscored and deliberated for years. In order to overcome this difficulty, it is imperative to consider the prerequisite for recruitment that metalwork technology graduates need in order to secure future employment successfully.

All over the world, employability among graduate is considered a problem. According to Kathleen [3], the employers in America are not pleased with many job applicants, particularly those who graduated from technical institutions. This problem occurs mostly because the applicants do not possess enough nontechnical skills. Many factors have attributed to the reasons for the unemployment of graduates. Rahmah, 
Ishak, and Wei Sieng [4] specified that graduates lack employability skills (non-technical skills) in Malaysia, which resulted in a low performance in the place of work. Rasul \& Mansor, [5] also revealed that there is a mismatch between skills that graduates acquired and the prerequisite demanded by employers that can make them perform effectively at work. Therefore, it is an indication that there is a need for non-technical skills enhancement among graduates. However, Caleb \& Udofia, [6] submitted that employability that hinges on soft skills will result in adaptation in diverse workplace settings. Similarly, Omar, Bakar \& Rashid [7] stated that technical skills development alone without soft skills (non-technical skills) could not provide assurance of employment.

As the current study is concerned with graduates of technical colleges, it is essential to briefly define metalwork technology in the context of technical education in Nigeria. The national board for technical education [8] referred to metalwork technology as a segment of technical and vocational education and training (TVET) programmes that are taught in technical colleges in Nigeria, which encompasses other subjects such as foundry craft practice, fabrication and welding, forging, machine shop, and equipment mechanic work. According to the Federal Republic of Nigeria in its national policy on education [9], one of the objectives of technical and vocational education is to create an opportunity for it recipients to be selfreliant and be employable.

Non-technical skills, on the other hand, focus on the graduates' abilities to adapt and use their personal and academic skills to create more tangible educational outcomes that associate graduate employability with employment. It also refers to the readiness of new graduates to contribute to their organizations in terms of skills, knowledge, and attitude, as well as pragmatic industry understanding [10]. Thus, the concept of employability can be observed in situations where new graduates are able to make themselves valuable to the organizations by possessing skills, knowledge, and attitude relevant to the requirement of the organizations. Generally, non-technical skills are needed by students to prepare themselves to meet the needs of many different occupations upon graduation. The current trend of employment increased the emphasis on such skills. As a result, there is a need for technical college's curriculum to incorporate opportunities to develop such skills in conjunction with subject-specific skills and knowledge for the purpose of enhancing the graduates' employability particularly in the field of metalwork technology.

Technical and vocational education is one of the fields of study that are particularly concerned with skills development that makes it recipients to be self-reliant, self-sufficient. These skills are meant to enable them to have easy access to suitable employment which could later translate to national economic development [11]. However, it has been established in various past studies that unemployment and skills mismatch among graduates are so rampant and critical [6]. This has generated worries throughout the world, and particularly among the developing nations. The "twin" problems (unemployment and skills mismatch) may not be unconnected with the ill-preparation of graduates with the skills demanded by employers for them to be relevant and employable. According to Tansen, [12] it has been difficult for various nations across the world to make provision for quality training that can bring about such transformation. Triki, [13] however, asserted that there is a need to make a link between institutions and industries. Invariably, this is translated into a need to consider the inclusion of non-technical skills into the curriculum of technical and vocational education. This study will situate the curriculum inclusion with a particular reference to metalwork technology in technical and vocational institutions as its focus.

The prime purpose of this study is to ascertain the views of professionals on non-technical skills considered as essential recruitment prerequisite among graduates of metalwork technology from technical and vocational institutions in Nigeria. Specifically, the study sought to identify the non-technical skills that are considered important recruitment prerequisite among graduates of metalwork technology of technical and vocational institutions in Nigeria. What are the non-technical skills considered important by professionals as recruitment prerequisite among graduates of metalwork technology of technical and vocational institutions in Nigeria?

\section{LITERATURE REVIEW}

Employers today are concerned about finding worthy employees who have not only the necessary academic skills like reading, writing, science, mathematics, oral communication and listening but also have higher order thinking skills like learning, reasoning, thinking creatively, decision making and problemsolving. They are also looking for employees who have personal qualities which include a sense of responsibility, self-confidence, self-control, social skill, honest, have integrity, adaptable and flexible, team spirit, punctual and efficient, self-directed, have good work ethics, being well-groomed, cooperative, selfmotivated, and self-managed. Savanee, et al., [14]; Dabalen et al., [15]; Nurkaliza et al., [16] have shown that employers believe that "university graduates are poorly trained and uncreative on the job, and deficiencies 
are mainly severe in oral and written communication and applied technical skills". According to Atsumbe et al., [17] and Mohamad et al. [18], the skills of graduates do not match with the requirements of employers. Hence, many graduates are found unemployed after graduation. Mohd Shamsuri, Saad \& Izaidin Ab., [19] revealed that the employability skills such as communication and interpersonal skills, problem-solving, entrepreneurial skills, and critical thinking skills are considered crucial by employers for graduates of engineering and information and communication (ICT) to be employable in the job market. Some scholars and commentators have argued that as far as the formal sector is concerned, the average graduate is not employable and, therefore, does not possess the skills needed by the employers of labor for formal employment.

Despite the continued efforts of government on TVET, the pace of technological progress employment and industrialization is still slow and unimpressive as evidenced by the rising unemployment rate and level of poverty in the country [20]. Maclean [21] asserts that TVET if well positioned could play multidimensional roles of stimulating economic growth, social development, improving conventional education, empowerment, wealth creation, poverty reduction and skills enhancement. In a nation with recurring incidences of youth restiveness, TVET is well suited to help youths and adults become selfdependent and self-reliant, while for those working in the industry, TVET is helpful in the areas of skills enhancement, mitigation of high job turnover and risks of obsolescence [22]. There are various definitions of employability skills as defined by the scholars, such as the basic skills necessary for getting, keeping and doing well in a job, and which cut horizontally across all industries and vertically across all jobs [23, 24]. According to Emilia and Maria [25], the society needs to give maximum importance to employment strategies as a viable solution for the multiple economic and social problems that Romania is confronted with in the national and international context.

The changing global employment market, competition, technological advances and patterns of demand require new employability skills from graduates for them to cope with varying conditions within the tourism business world [26]. Depending on the nature of the vacancies, firms often require people with some work experience and the ability to, at least to some extent, work independently. As Mlatsheni [27] highlights, work experience is an "important factor that influences employability at all levels". Employers are also riskaverse and prefer to employ older, more experienced workers who do not require as large an investment in training, given the threat of headhunting in a scarce skills economy.

\section{RESEARCH METHOD}

This research is a survey using a structured questionnaire to ascertain the view of professionals on the non-technical skills that are considered as important recruitment prerequisite among graduates of metalwork technology from technical and vocational institutions in Nigeria. Seventy (70) respondents who consisted of professionals in the field of metalwork technology were purposively selected to determine their perceptions on recruitment prerequisite metalwork technology graduates. The instrument consisted of thirty two (32) items, which were covers the seven components of non-technical skills that are categorized as follows: Communication Skills; (i) ability to speak clearly with purpose, (ii) ability to write good report; Teamwork Skills; (i) ability to work cooperatively with others, (ii) ability to contribute ideas in a team work; Learning Skills; (i) ability to acquire knowledge and grow continuously, (ii) ability to acquire skills continuously; Creative Thinking skills; (i) ability to create ideas, (ii) ability to imagine solution; Decision Making Skills; (i) ability to implement recommendation, (ii) ability to evaluate decision; Self-Management Skills; (i) ability to manage time proficiently, (ii) ability to maintain personal integrity; Problem Solving Skills; (i) ability to identify problem and the causes, (ii) ability to establish clear project goals and objectives etc. This was specifically carried out in Ogun State of Southwestern Nigeria. The instrument comprised of five points Likert scale of response choices that range from the most important (MI), very important (VI), important (I), slightly important (SI), and not important (NI) respectively. The data were collected and analyzed by employing SPSS statistical tool.

The summary of the data presented in Table 1 reveals that all the 36 items of non-technical skills have the mean scores of more than 3.00 which indicate that these items are very important for the recruitment of metalwork technology graduates in technical and vocational colleges in Nigeria. 
Table 1. Mean rating with a standard deviation of the respondents

\begin{tabular}{llccl}
\hline & & $\bar{X}$ & SD & Remark \\
\hline 1 & Communication Skills & 4.03 & 0.26 & Important \\
2 & Teamwork Skills & 3.40 & 0.24 & Important \\
3 & Learning Skills & 3.90 & 0.26 & Important \\
4 & Creative Thinking skills & 3.40 & 0.24 & Important \\
5 & Decision Making Skills & 3.70 & 0.29 & Important \\
6 & Self-Management Skills & 3.04 & 0.24 & Important \\
7 & Problem Solving Skills & 3.70 & 0.27 & Important \\
& $\quad$ Grand Mean & \multicolumn{2}{c}{3.60} & \\
\hline
\end{tabular}

\section{RESULTS AND DISCUSSION}

Based on the literature reviewed, it was observed that studies in the areas of technical and vocational education units as related to the non-technical skills that are considered as important for graduates of metalwork technology of technical institutions in Nigeria. Even though technical and vocational education has received attention as an entity by some researchers, consideration still requires more of its units. Also, subsequent to the critical examination of all the papers chosen for this study, it was found that recruitment conditions of the employers in the contexts of TVE fall into three major categories: professional skills, soft/non-technical skills, and entrepreneurial skills [6, 12, 2]. Whereas, considerable emphasis was also laid on the non-technical skills as essentials for graduates to be employed. However, the most common components of the non-technical skills that are considered as important for technical colleges in Nigeria have been identified as communication skills, teamwork skills, interpersonal skills, critical thinking skills, selfmanagement skills, problem-solving, and leadership skill among others. Whereas it was found that graduates in technical education with both professional skills and non-technical skills/soft skills have more advantage to secure suitable employment [6]. Maripaz et al., [28]; Inga, and Deniss, [29] also agreed that employers offer special consideration to non-technical skills over specific job skills.

However, the result of this study indicated that the following non-technical skills: communication, teamwork, learning, creative thinking, decision-making, self-management and problem-solving skills are essential to metalwork technology graduates from technical colleges in Nigeria to be employable. These findings conform to the findings of Caleb \& Udofia, [6] who found that the students of Electrical installation in technical colleges of Akwa Ibom State in Nigeria needed generic skills for employability. It is also in alignment with a study by Rasul, \& Mansor, [5] who found that employers are very particular, and they need graduates who are equipped to work.

\section{CONCLUSION}

This study has been able to identify the importance of non-technical skill as complementary to the professional skills of graduates in the field of technical and vocational education as one of the conditions for accessing suitable employment. There is a need, therefore, to integrate it into metalwork technology curriculum across technical institutions in Nigeria. It is consequently pertinent to further suggest that the essential of non-technical skills in all TVE institutions should be more emphasized. Students should be sensitized on the employers' recruitment prerequisites while they are still in schools in order to prepare their mind ahead of time.

There is no gainsaying that researchers worldwide have made frantic and commendable efforts in diverse ways for searching dependable solution to put unemployment menace among graduates/youths to a halt or reducing it drastically to a bearable level. This has in no less measure manifested in various studies on skills development of students, youth empowerment, and graduates employability alike. However, it is believed that research in this direction is yet to be exhausted, hence this study suggests an additional investigation on skills development particularly non-technical skills acquisition that more focus should be extended towards units of technical and vocational education such as mechanical/metalwork technology, electrical/electronic technology, building/woodwork technology among others. This will further enable researchers to have an in-debt search to the prevailing problems that lead to unemployment and skills mismatch and thereby find a lasting solution that will make graduates from technical and vocational education institutions be employable.

\section{REFERENCES}

[1] Lindsay, C., "Long-term unemployment and the "employability gap": Priorities for renewing Britain's New Deal," Journal of European Industrial Training, vol. 26(9), pp. 411-419, 2002.

[2] Titus K. M., "Relationship between technical and vocational acquired skills and skills required in job market; evidence from TVET Institutions, Uasin Gishu County Kenya," Journal of Education and Practice, vol. 4(19), 2013.

The non-technical skills needed by graduates of technical colleges in metalwork ... (Bakare Shola F) 
[3] Kathleen, C., "Developing employability skills. Regional educational laboratory," School Improvement Research Series (SIRS), 2005.

[4] Rahmah, I., Ishak, Y., \& Wei Sieng, L., "Employers' perception of graduates in Malaysia service sector," International Business Management, vol. 5(3), pp.184-193, 2011.

[5] Rasul, M. S., \& Mansor, A. N., "Employability skills indicator as perceived by manufacturing employers," Asian Social Science, vol. 9(8), p. 42, 2013.

[6] Caleb, E., Udofia, A., "Generic skills and the employability of electrical installation students in technical colleges of Akwa Ibom State, Nigeria," IOSR Journal of Research \& Method in Education vol. 1(2), pp.59-67, 2013.

[7] Omar, M. K., Bakar, A. R., \& Rashid, A. M., "Employability skill acquisition among Malaysia community college student," Journal of Social Sciences. Science Publication; vol. 8(3), pp. 472-478, 2012.

[8] NBTE, "Directory of accredited progammes in Politechnics, Similar Tertiary Institutions, Technical Colleges and Vocational Enterprise Institutions In Nigeria," Kaduna: Bida Road, 2011.

[9] NPE, The Federal Republic of Nigeria: National Policy on Education, 2004.

[10] Mason, G.W., Williams, G. and Crammer, S., Employability skills initiatives in higher education: what effects do they have on graduate labour outcomes? (2006), 5 November 2014, http://www.hefce.ac.uk/pubs/rdreports/ 2003/rd13_03/default.asp

[11] Osami, I. "Implementing vocational and technical education programmes in South-South Nigeria: A case of rivers state," International Journal of Scientific Research in Education, vol. 6(2), pp. 128-148, 2013.

[12] Tansen, M. H. "Public-Private Partnership (PPP) in the Technical Vocational Education and Training (TVET) Sector in Bangladesh: Challenges and Prospects," TVET Project, Save the Children in Bangladesh, 2012.

[13] Triki, N. M. Higher Technical and Vocational Education and Training Programmes and Its Impact on the Libyan Manufacturing Industry, 2013.

[14] Savanee S., Duankamol T., Suwimon W., "Employment conditions and essential employability skills required by employers for secondary school graduate," Procedia Soc. Behav. Sci., vol. 116, pp. 1848-1854. 2014.

[15] Dabalen, A., Oni, B., and Adekola, O.A. "Labor market prospects for university graduates in Nigeria," Higher Education Policy, vol. 14(2), pp. 141-159, 2000.

[16] Nurkaliza K., Nor 'Adha Abd H., Rahmatunnisah S., Norziah O., Abdul Hadi A., Mohd Farok M. N., "Importance of soft skills for industrial training program: Employers' perspective," Asian Journal of Social Sciences \& Humanities, vol. 3(4), pp. 10-18, 2014.

[17] Atsumbe, B.N., Emmanuel, R., Igwe, C.O. Atsumbe, J. A., "Repositioning vocational and technical education for effective manpower production in Nigeria," Journal of Mechanical and Civil Engineering, vol. 1(4), pp. 41-43, 2012.

[18] Mohamad S. R., Mohd Y. I., Napsiah I., Muhammad R. R. and Rose Amnah Abd R., "Importance of employability skills as perceived by employers of Malaysian Manufacturing Industry," Journal of Applied Sciences Research, vol. 5(12), pp. 2059-2066, 2009.

[19] Mohd Shamsuri Md Saad, Izaidin Ab. Majid., "Employers' perceptions of important employability skills required from Malaysian Engineering and Information and Communication Technology (ICT) Graduates," Global Journal of Engineering Education, vol. 16(3). 110-115, 2014.

[20] Ladipo, M. K., Akhuemonkhan, I. A. and Raimi, L. "Technical Vocational Education and Training (TVET) as a mechanism for Sustainable Development in Nigeria (SD): Potentials, Challenges, and Policy Prescriptions," Presentation at CAPA International Conference held in Banjul, The Gambia, June 3-8, 2013.

[21] Maclean, R., "Key issues and research challenges for TVET: Bridging the gap between TVET research and the needs of policymakers," in NORRAG NEWS, Towards a New Global World of Skills Development? TVET's turn to make its Mark, no.46, pp. 125-127, 2011.

[22] Okolocha, C. C., "Vocational technical education in Nigeria: Challenges and the way forward," Business Management Dynamics, vol. 2(6), pp. 1-8, 2012.

[23] Gurcharan Singh, G.K. and Garib Singh, S.K., "Malaysian graduates' employability skills," Unitar E-J., vol. 4(1), pp. 15-31, 2008.

[24] Robinson, J.P., "What are employability skills?" Alabama Cooperative Extension System. vol. 1(3), pp. 1-3, 2000.

[25] Emilia H., Maria Ana G., "Employment strategy for poverty reduction. A Romanian perspective. Procedia - Social and Behavioral Sciences, vol. 58, pp. 406-415, 2012.

[26] Zehrer, A. \& Mossenlechner, C., "Key competencies of tourism graduates: The employers' point of view," Journal of Teaching in Travel \& Tourism, vol. 9(3-4), pp. 266-287, 2009.

[27] MLATSHENI, C., "The youth labour market: What does it take to succeed?" Mimeo, 2005.

[28] Maripaz A., Ombra A. I., and Shuki O., "Employability skills and task performance of employees in government sector," International Journal of Humanities and Social Science. vol. 3(4), pp. 150-162, 2013.

[29] Inga, L. and Deniss, S, Employability and skills anticipation: competences and market demands, 2014.

Int. J. Eval. \& Res. Educ. Vol. 8, No. 4, December 2019: 654 - 658 